\title{
Osteosarcoma Arising from a Haemangioma: Case Report and Review of the Literature
}

\author{
Hemangiomdan Köken Alan Osteosarkom: \\ Olgu Sunumu ve Literatürün Gözden Geçirilmesi
}

\author{
Paul MALLINSON ${ }^{1}$, Tyler COUPAL ${ }^{2}$, Malcolm HAYES ${ }^{3}$, Paul CLARKSON ${ }^{4}$, Peter MUNK ${ }^{1}$, Hugue OUELLETTE ${ }^{1}$ \\ ${ }^{1}$ Department of Radiology, Vancouver General Hospital/University of British Columbia, VANCOUVER/BC, CANADA \\ 2McMaster University, De Groote Medical School, HAMILTON/ONTARIO, CANADA \\ Departments of ${ }^{3}$ Pathology and ${ }^{4}$ Surgery, BC Cancer Agency, VANCOUVER BC, CANADA
}

\begin{abstract}
To create awareness of the benign lesions from which osteosarcoma may arise.

Osteosarcoma is a rare tumour of bone the etiology of which is poorly understood, but it may arise from benign lesions. Malignant transformation in hemangiomas, in the absence of prior radiation, is exceedingly rare and the resulting neoplasm is usually an angiosarcoma. We report the case of a 30-year-old woman where investigation for thigh pain revealed a distal femoral hemangioma. She represented with pain and mass 18 years later, leading to a confirmed diagnosis of osteosarcoma at the same site.
\end{abstract}

Osteosarcomas may arise from a variety of benign lesions. In this article we report the case of a histologically confirmed hemangioma which subsequently underwent malignant change into an osteosarcoma.

Key Words: Osteosarcoma, Neoplastic cell transformation, Hemangioma

\section{INTRODUCTION}

Osteosarcoma is a rare tumour of bone the etiology of which is poorly understood. Malignant transformation of hemangiomas, in the absence of prior radiation, is exceedingly rare, with only a handful of reported cases (1). Reports in the literature describe osteosarcomas arising from a variety of benign lesions and conditions, but the authors found no reports of transformation from a hemangioma. In this article we report the case of a histologically confirmed haemangioma which underwent malignant change into an osteosarcoma 18 years after the original diagnosis.

\section{CASE REPORT}

A 30-year-old woman was investigated for distal thigh pain. An x-ray was performed and showed an area of bone scle-

(Turk Patoloji Derg 2014, 30:137-141)

Received : 14.08.2013 Accepted : 25.09.2013

\section{ÖZ}

Benign bir lezyondan osteosarkom gelişebileceğine dikkat çekmek.

Kemiğin nadir bir tümörü olarak osteosarkom etyolojisi anlaşılamamış bir tümör olup, iyi huylu lezyonlardan da gelişebilir. Hemanjiomun öncesinde radyoterapi hikayesi olmaksızın malign transformasyonu ileri derecede nadir olup, bu genellikle anjiyosarkom yönündedir. $\mathrm{Bu}$ yazıda sağ uyluk ağrısı nedeni ile incelenen 30 yaşında bir kadın hastada saptanan distal femoral kemik yerleşimli hemanjiom olgusunu sunmak istedik. Hastanın özelliği bu tanıdan 18 yıl sonra aynı bölgede osteosarkomla uyumlu kitle ile tekrar baş vurmuş olmasıdır.

Osteosarkomlar değişik benign lezyonlardan çıkabilir. Bu yazıda histolojik olarak tanısı doğrulanmış intraosseöz bir hemanjiom zemininde osteosarkom yönünde malign transformasyon gösteren bir olguyu sunmaktayı.

Anahtar Sözcükler: Osteosarkom, Neoplastik hücre dönüşümü, Hemanjiom

rosis in the distal lateral femoral metaphysis measuring 3.5 $\mathrm{cm}$ in maximum dimension. The anterior margin was well delineated but the other margins were indistinct. Diagnoses of fibrous dysplasia and sarcoma were considered. A repeat $\mathrm{x}$-ray a month later again demonstrated the same sclerotic lesion without evidence of cortical destruction or periosteal reaction. A bone scan demonstrated uptake in the region of the lesion with no evidence of metastatic disease. MRI showed that the lesion extended to the epiphysis but showed no evidence of cortical perforation or joint involvement. Some surrounding bone marrow edema was noted.

An initial core needle biopsy was non-diagnostic and a large open trephine biopsy was therefore performed. The sections showed dense sclerotic bone lesion exhibiting remodelling of lamellar bone trabeculae. This was associated

Correspondence: Paul MALLINSON

Vancouver General Hospital/University of British Columbia,

Department of Radiology, VANCOUVER/BC, CANADA

E-mail: dr_pmallinson@hotmail.com Phone: +1 6043583547 
with prominent activity of both osteoblasts and osteoclasts, but no osteoblastic cytological atypia was seen. The intertrabecular tissue showed a proliferation of crowded thinwalled blood vessels lined by flat endothelial cells, again lacking atypia, and associated with interspersed erythro-
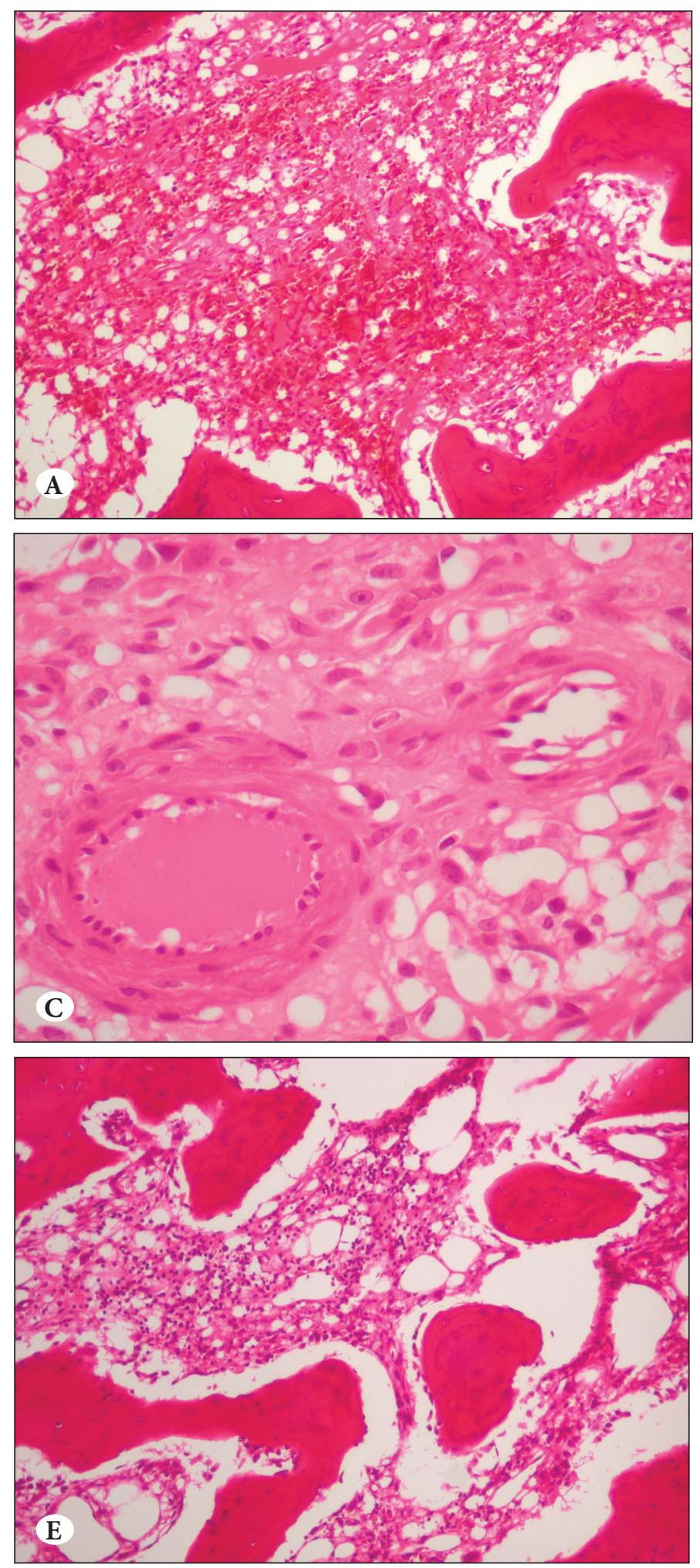

cytes. The features were those of an intraosseous hemangioma (Figure 1A,E). There was no evidence of malignancy. The slides were reviewed by 2 experienced pathologists who concurred with this interpretation.
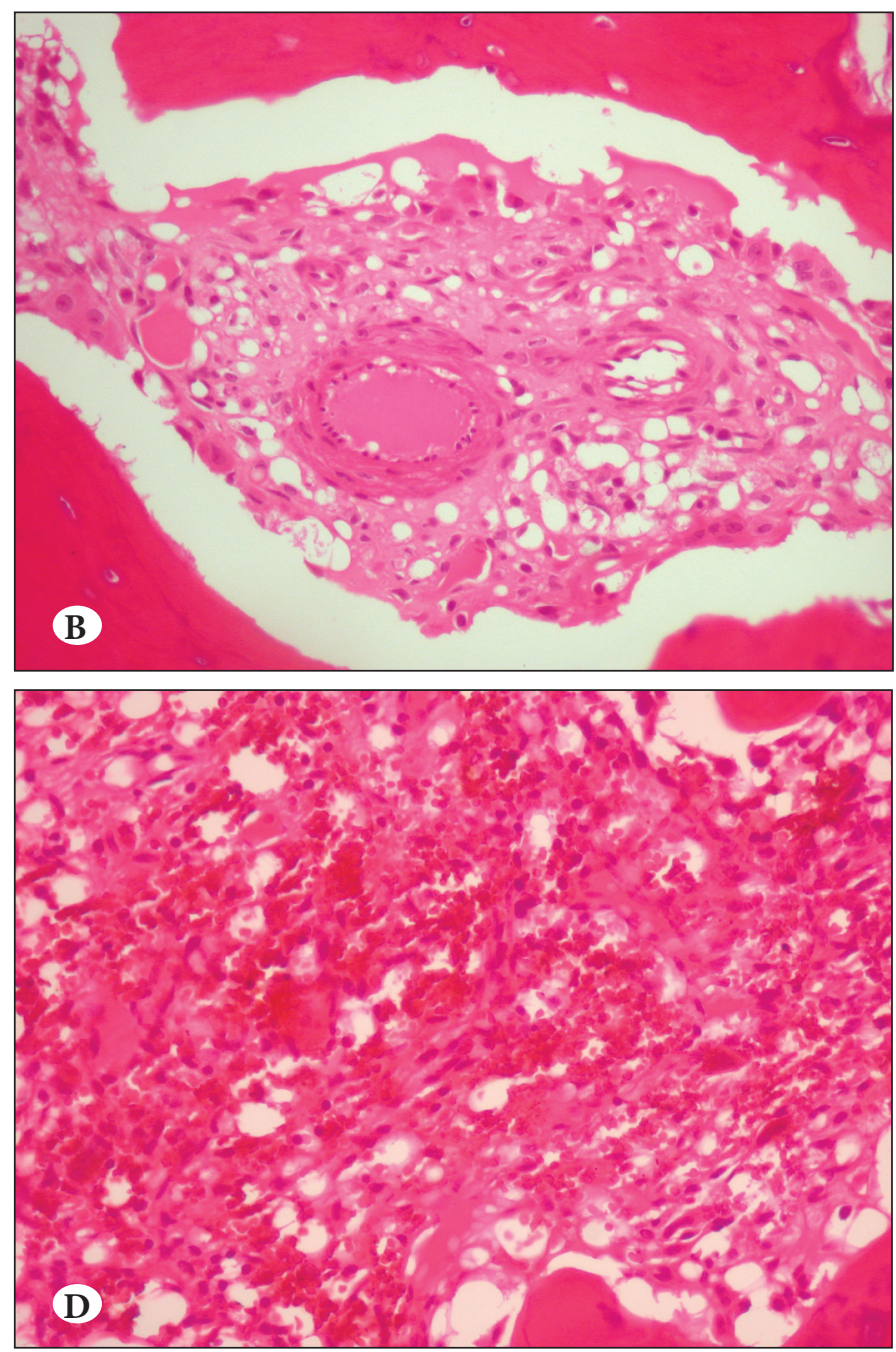

Figure 1: A) Biopsy from 1994 showing a proliferation of crowded thin-walled blood vessels lined by flat endothelial cells, lacking atypia, and associated with interspersed erythrocytes, diagnostic of a benign hemangioma (H\&E x100). B) Clusters of vessels surrounded by normal bone in keeping with a benign hemangioma (H\&E x200). C) Multiple vessels, spindle cells and a capillary lumen in keeping with a benign hemangioma $(\mathrm{H} \& \mathrm{E}$ $\mathrm{x} 400$ ). D) A mass of red cells and blood vessels in keeping with a benign hemangioma (H\&E x200). E) Spongy appearance with proliferative abnormal vessels interspersed between reactive bone trabeculae, in keeping with a intraosseous benign hemangioma (H\&E x100). 
Seventeen years later, the patient re-presented with an enlarging painful mass of the left knee that was associated with dysesthesia at the anterior aspect of the left leg and

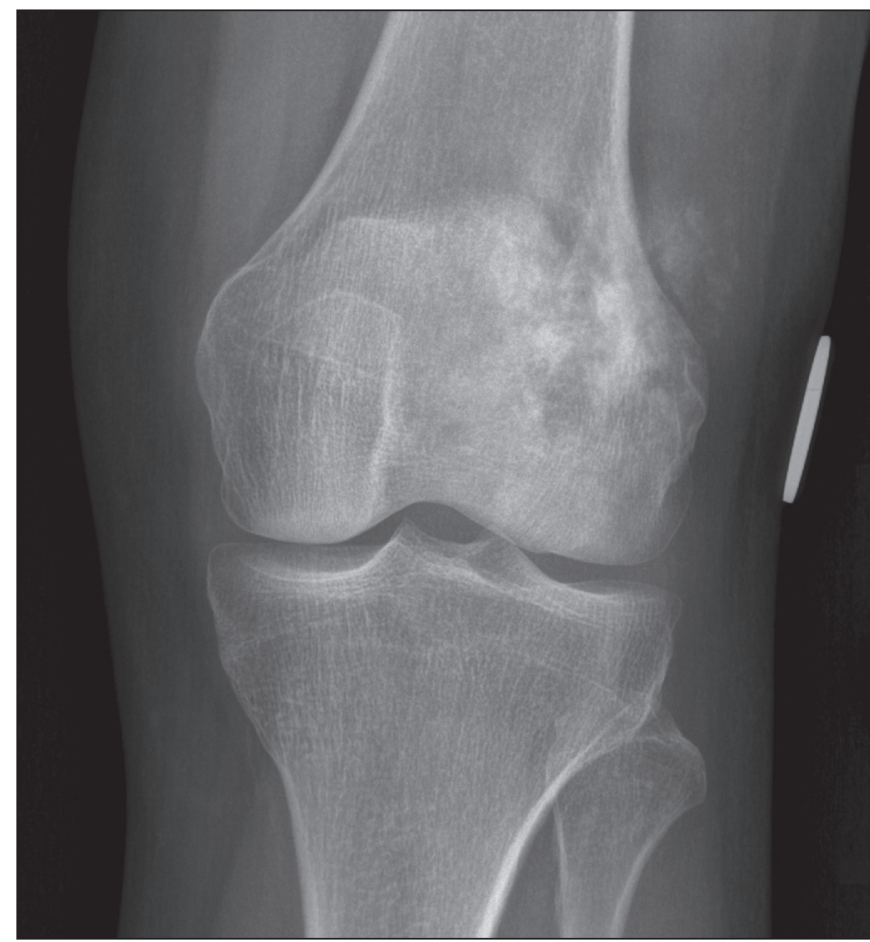

Figure 2: X-ray at time of re-presentation showing a lytic sclerotic lesion in the lateral femoral condyle with cortical breach and ill defined calcification in the adjacent soft tissue. foot. Physical examination was otherwise normal. The patient was otherwise healthy, took simple analgesics for shoulder pain and no other medication.

The repeat $\mathrm{x}$-ray demonstrated an aggressive process, featuring poorly marginated area of sclerosis/lysis occupying the lateral femoral condyle with cortical destruction laterally and ill-defined calcification in the adjacent soft tissues (Figure 2). CT confirmed a lytic/sclerotic bony lesion with

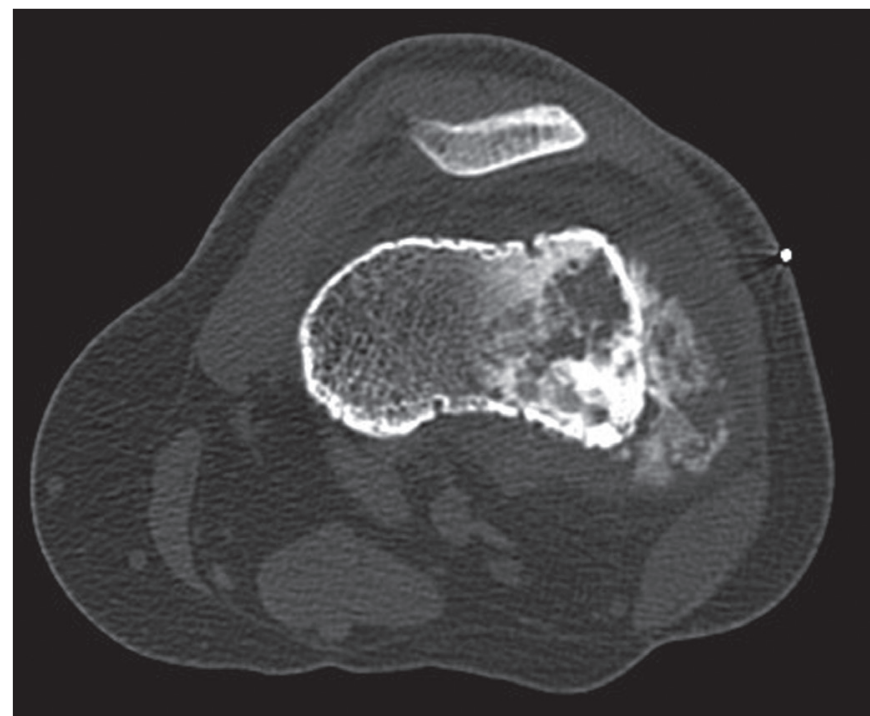

Figure 3: Axial CT showing a lytic sclerotic lesion in the lateral femoral condyle with cortical breach and osteoid matrix.

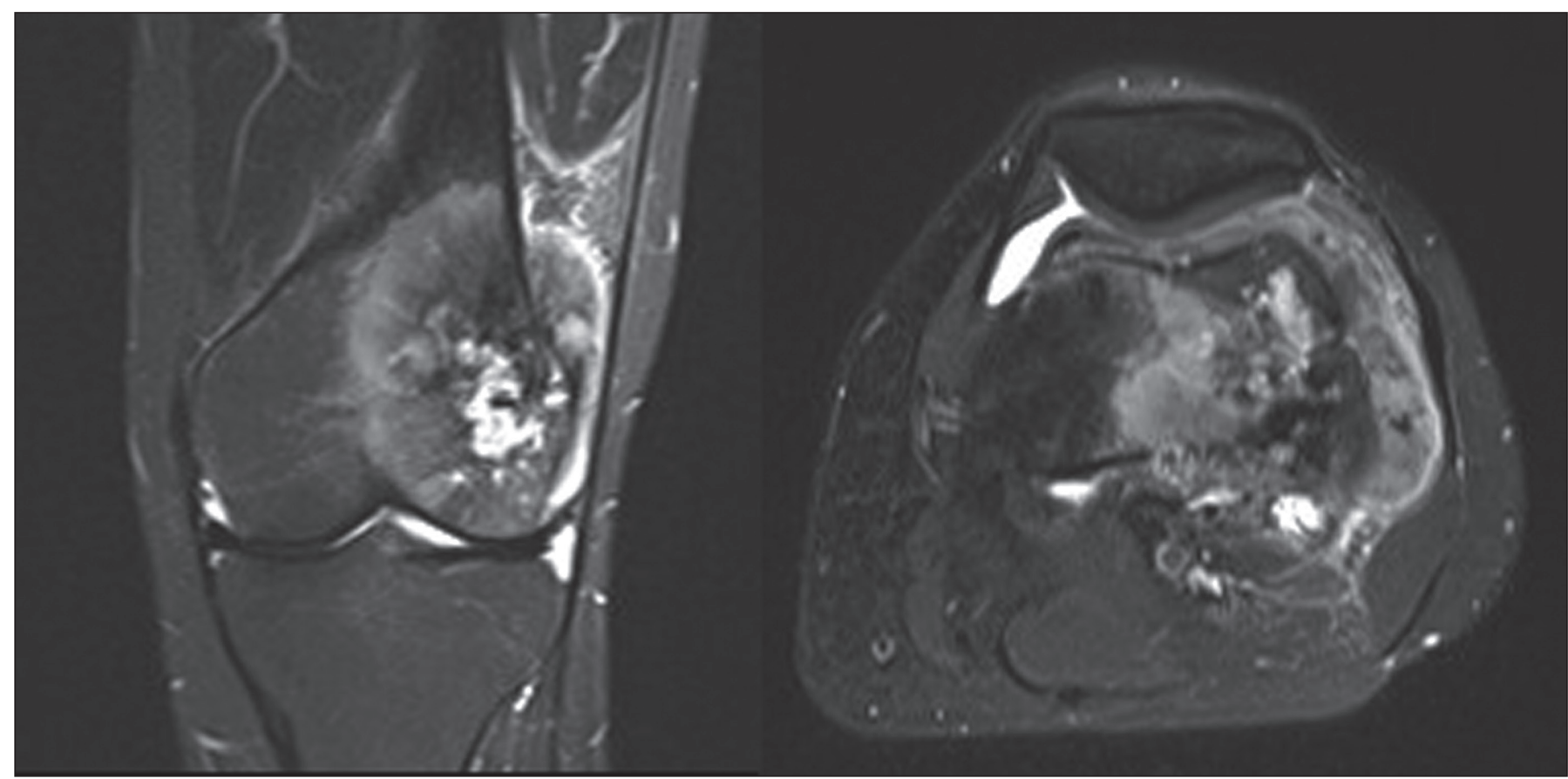

Figure 4: MRI Coronal STIR and Axial T2W FS images demonstrating the lateral femoral condyle lesion breaching the cortex and extending into the soft tissue with surrounding edema. 
cortical perforation, periosteal reaction and calcified matrix (Figure 3). MRI further affirmed the aggressive nature of lesion that showed a soft tissue component seen extending through the breached cortex into the adjacent muscle, with surrounding edema (Figure 4). The lesion measured $6.6 \times 5.1 \times 5.3 \mathrm{~cm}$ and showed hypointensity on T1W images and heterogeneous hyperintensity on T2W images. The lesion was again positive on bone scan but with no evidence of bone metastases. Diagnoses of osteosarcoma, chondrosarcoma and calcified metastases from a mucinous tumour were considered.

A CT-guided core biopsy was performed using an $11 \mathrm{G}$ coaxial needle and a $14 \mathrm{G}$ biopsy needle via a lateral approach. The histology sections demonstrated trabeculae of lamellar bone permeated by a high-grade malignant spindle and polygonal cell neoplasm. This was associated with production of osteoid matrix and irregular woven bone trabeculae, characteristic of an osteosarcoma (Figure 5A-D). No residual hemangioma was identified.

\section{DISCUSSION}

Malignant transformation in hemangiomas is most commonly associated with radiation therapy and is otherwise very rare. The malignant change has previously been to an angiosarcoma $(1,2)$. Our patient had no history of prior radiation therapy to the distal femur. Osteosarcomas usually arise de novo. Radiation has been implicated and Paget's disease is a known cause in the older generations.
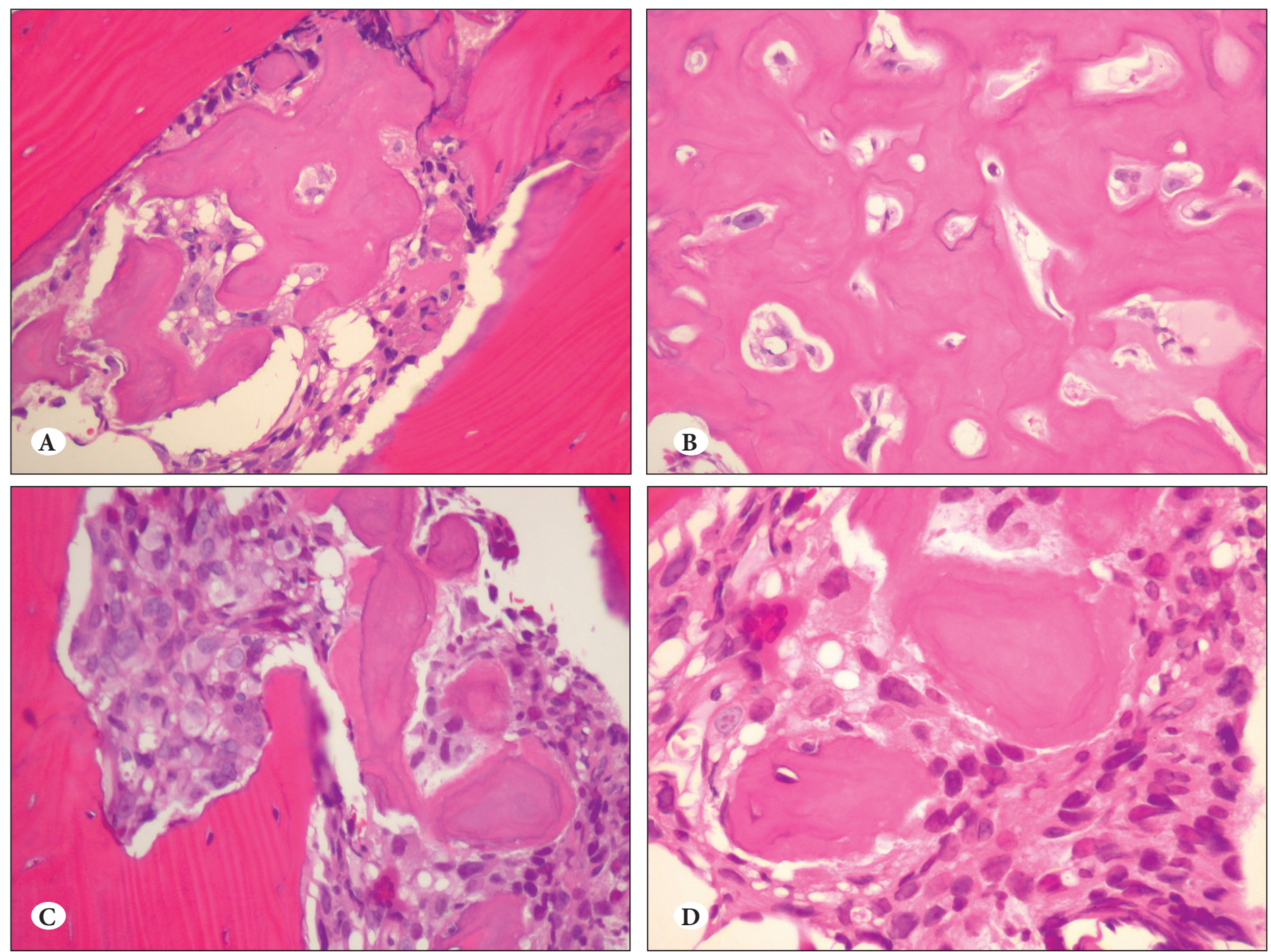

Figure 5: A) Biopsy from 2012 demonstrating lamellar bone permeated by a high grade malignant spindle and polygonal cell neoplasm, with osteoid matrix and irregular woven bone trabeculae, diagnostic of a high grade osteosarcoma (H\&E x200). B) Woven bone and large malignant osteoblasts (H\&E x200). C) Preexisting lamellar bone trabeculae permeated by sheets of tumour cells and woven bone in keeping with osteosarcoma (H\&E x200). D) Malignant osteoblastic tumoral cells admixed with woven bone in keeping with osteosarcoma (H\&E x200). 
Associations have also been made with tall stature, pubertal hormones, acromegaly, viruses and various cancer predisposition syndromes including retinoblastoma (3).

Osteosarcomas have been reported to arise from heterotopic bone secondary to dermatomyositis and thermal injury, giant cell tumors (GCT), irradiated aneurysmal bone cysts $(\mathrm{ABC})$, osteoblastomas, solitary osteochondromas and fibrous dysplasia (4-9). Malignant change in GCTs is most commonly reported after radiation, but can be spontaneous and has even occurred in a GCT lung metastasis (6).

Difficulty in histological diagnosis of osteosarcoma has been reported when the differential includes other osteoid producing tumours, but distinction from hemangioma is usually simple. Bertoni et al. described 17 cases of osteosarcoma that resembled osteoblastoma on histological analysis (10). In the present case, the original histological appearances were distinctly different from osteosarcoma and the diagnosis of hemangioma was confirmed by 3 pathologists on the basis of a large open trephine biopsy. Furthermore, the time interval was sufficiently long to exclude a misdiagnosed indolent osteosarcoma due to a sampling error.

Osteosarcoma is the most common primary sarcoma of bone, but remains rare (estimated 1-2 cases per million/ population/year for 25-59 age group) (3). The possibility of a coincidental osteosarcoma arising at the site of a hemangioma is statistically unlikely in the absence of other known predisposing factors, but has to be considered. The increased rate of bone turnover induced by the hemangioma could have acted as a substrate for the development of a secondary malignancy in a similar mechanism to the development of osteosarcoma in Paget's disease.

The period of time taken for the malignant transformation was 18 years. Previous reports of malignant transformation to osteosarcoma in the literature cover a wide range of timescales including 28 years for a case of dermatomyositis case (5), 6 years for a GCT (6) and 7 years for an ABC (7). Obana reported that the time taken for a hemangioma to undergo malignant change to angiosarcoma as 2 years (2). Our case falls within this very wide spectrum.

In conclusion we present the unique case of an osteosarcoma arising from a hemangioma 18 years after original diagnosis.

\section{REFERENCES}

1. Rossi S, Fletcher CD. Angiosarcoma arising in hemangioma/ vascular malformation: Report of four cases and review of the literature. Am J Surg Pathol. 2002; 26:1319-29.

2. Obana Y, Tanji K, Furuta I, Yamazumi T, Hashimoto S, Kikuchi $\mathrm{H}$, Tanaka S, Ohba Y. A case of malignant transformation in thoracic vertebral hemangioma following repetitive irradiation and extraction. Pathol Int. 1996; 46:71-8.

3. Savage SA, Mirabello L. Using epidemiology and genomics to understand osteosarcoma etiology. Sarcoma. 2011; 2011:548151.

4. Ueno H, Ariji E, Tanaka T, Kanda S, Mori S, Goto M, Mizuno A, Okabe H, Nakamura T. Imaging features of maxillary osteoblastoma and its malignant transformation. Skeletal Radiol. 1994; 23:509-12.

5. Eckardt JJ, Ivins JC, Perry HO, Unni KK. Osteosarcoma arising in heterotopic ossification of dermatomyositis: Case report and review of the literature. Cancer. 1981; 48:1256-61.

6. Brien EW, Mirra JM, Kessler S, Suen M, Ho JK, Yang WT. Benign giant cell tumor of bone with osteosarcomatous transformation ("dedifferentiated" primary malignant GCT): Report of two cases. Skeletal Radiol. 1997; 26:246-55.

7. Aho HJ, Aho AJ, Einola S. Aneurysmal bone cyst, a study of ultrastructure and malignant transformation. Virchows Arch A Pathol Anat Histol. 1982; 395:169-79.

8. Nojima T, Yamashiro K, Fujita M, Isu K, Ubayama Y, Yamawaki S. A case of osteosarcoma arising in a solitary osteochondroma. Acta Orthop Scand. 1991; 62:290-2.

9. Aboulafia AJ, Brooks F, Piratzky J, Weiss S. Osteosarcoma arising from heterotopic ossification after an electrical burn. A case report. J Bone Joint Surg Am. 1999; 81:564-70.

10. Bertoni F, Unni KK, McLeod RA, Dahlin DC. Osteosarcoma resembling osteoblastoma. Cancer. 1985; 55:416-26. 